10. Serio, P. (1993). About the language of power: a critical analysis. Philosophy of language: within and outside borders. Vol. 1. Kharkiv: Oko [in Ukrainian].

11. Sossyur, F. de. (1998). General Linguistics Course. (N. A. Sliusarevoi, Trans). Moskow: Logos [in Russian].

Стаття надійшла до редакції 14.06.2019 p.

Удк 342(477)

\author{
Бєлов Дмитро Миколайович. \\ доктор юридичних наук, професор, \\ ДВНЗ «Ужгородський національний університет» \\ ORCID 0000-0002-7168-9488 \\ belov_dimon@yahoo.com \\ Шандра Богдана Богданівна \\ кандидат юридичних наук, доцент, \\ ДВНЗ «Ужгородський національний університет» \\ ORCID 0000-0003-4104-2744 \\ bogdana.shandra@uzhnu.edu.ua
}

\title{
КУЛЬТУРОЛОГІЧНІ ФАКТОРИ ТА ПРИРОДА КОНСТИТУЦІЙ: ІСТОРІЯ ТА СУЧАСНІСТЬ
}

Метою статті є з'ясування місця та ролі культури у процесі формування основ конституціоналізму в державі та зокрема Конституції як Основного Закону держави. Методологічну основу складає постпозитивістська методологія дослідження проблем сучасного українського конституціоналізму, яка $є$ упорядкованою системою взаємоузгоджених світоглядних принципів і методів, що дозволяють усебічно та комплексно дослідити юридичні властивості конституціоналізму та визначити сутність i зміст правових зв'язків між ії основними структурними елементами. Наукова новизна полягає у тому, що в робота є комплексним науковим дослідженням сучасної української науки, в якому обґрунтовано цілісну наукову теорію культурних фракторів у Основному Законі, покликану розуміти й пояснювати науку конституційного права виходячи з певних концептуальних основоположень. Висновки. Саме Конституція є тим фундаментом, який визначає формування і розвиток правової культури в державі. Тому ми повинні керуватися правилом: яка Конституція країни, така і її правова культура. Крім того, вважаємо, що, на жаль, конституційний процес сьогодні надто політизований. На нашу думку, триває найгостріша політична боротьба за прийняття зручної для однієї з сторін форми конституції. А фактично - за владу - всі хочуть максимум влади. У тому числі й через проведену якимсь чином свою Конституцію. Однак Основний Закон повинен прийматися не з кон'юнктурних міркувань політичної доцільності, а бути повноцінним юридично вивіреним документом з урахуванням досягнень світового правознавства, з найсуворішим дотриманням усіх передбачених юридичних процедур. Адже конституція повинна бути головним документом держави, принаймні, на десятиріччя.

Ключові слова: сучасний український конституціоналізм, конституційний лад, конституція, перетворення конституції, конституційне законодавство, конституційно-правова реформа, культура, правова культура.

Белов Дмитрий Николаевич, доктор юридических наук, профессор, ГВУЗ «Ужгородский национальный университет»; Шандра Богдана Богдановна, кандидат юридических наук, доцент, ГВУЗ «Ужгородский национальный универсиmem»

Культурологические факторы и природа конституции: история и современность

Целью статьи является выяснение места и роли культуры в процессе формирования основ конституционализма в государстве и в частности Конституции как Основного Закона государства. Методологическую основу составляет постпозитивистская методология исследования проблем современного украинского конституционализма, которая является упорядоченной системой взаимосогласованных мировоззренческих принципов и методов, позволяющих всесторонне и комплексно исследовать юридические свойства конституционализма и определить сущность и содержание правовых связей между ее основными структурными элементами. Научная новизна заключается в том, что в работа является комплексным научным исследованием современной украинской науки, в котором обоснованно целостную научную теорию культурных фракторов в Основном Законе, призванную понимать и объяснять науку конституционного права исходя из определенных концептуальных основоположений. Выводы. Именно Конституция является тем фундаментом, который определяет формирование и развитие правовой культуры в государстве. Поэтому мы должны руководствоваться правилом: какая Конституция страны, так и ее правовая культура. Кроме того, считаем, что, к сожалению, конституционный процесс сегодня слишком политизирован. По нашему мнению, продолжается острая политическая борьба за принятие удобной для одной из сторон формы конституции. А фактически - за власть - все хотят максимум власти. В том числе и из-за проведенную каким-то образом свою Конституцию. Однако Основной Закон должен приниматься не из конъюнктурных соображений политической целесообразности, а быть полноценным юридически выверенным документом с учетом достижений мирового правоведения, со строжайшим соблюдением всех предусмотренных юридических процедур. Ведь конституция должна быть главным документом государства, по крайней мере, на десятилетие.

Ключевые слова: современный украинский конституционализм, конституционный строй, конституция, преобразования конституции, конституционное законодательство, конституционно-правовая реформа, культура, правовая культура.

Belov Dmytro, Doctor of Laws, Professor, Uzhgorod National University; Shandra Bogdana, Candidate of Juridical Sciences, Docent, Uzhgorod National University

Cultural factors and the nature of the constitutions: history and modernity

The purpose of the article. The purpose of the article is to find out the place and role of culture in the process of forming the foundations of constitutionalism in the state, and in particular the Constitution as the Basic Law of the state. The methodological basis is the post-positivist methodology of research into the problems of contemporary Ukrainian constitutionalism, which is an orderly system of mutually agreed ideological principles and methods that allow to study comprehensively and comprehensively the legal properties of constitutionalism and to determine the essence and content of legal links between its basic elements. The scientific novelty is that the work is a comprehensive scientific study of modern Ukrainian science, which substantiates a comprehensive scientific theory of cultural

(С Бєлов Д. М., 2019

(С) Шандра Б. Б., 2019 
factors in the Basic Law, designed to understand and explain the science of constitutional law based on certain conceptual foundations. Conclusions. It is the Constitution that determines the formation and development of the legal culture in the state. Therefore, we must follow the rule: what are the Constitution of the country and its legal culture. In addition, we believe that, unfortunately, the constitutional process is too politicized today. In our view, the fiercest political struggle to adopt a form of constitution suitable for one party is ongoing. And in fact - for power - everyone wants the maximum of power. Including through its own Constitution, which was somehow implemented. However, the Basic Law must be adopted not for reasons of political expediency, but to be a fully legally valid document, taking into account the achievements of world law, with the strictest adherence to all legal procedures. After all, the constitution should be the main document of the state for at least a decade.

Key words: modern Ukrainian constitutionalism, constitutional order, constitution, constitutional transformation, constitutional legislation, constitutional reform, culture, legal culture.

Актуальність теми дослідження. Будучи продуктом загальнолюдської і національної культури, конституція нерідко стає джерелом ідей для художників, архітекторів і навіть поетів, тим самим викликаючи появу, як мінімум, нових пам'ятників матеріальної культури, через які вона нерідко надає посилений емоційний вплив на населення тієї чи іншої держави. Так, наприклад, на одній з центральних вулиць Мадрида розташований великий кам'яний порожнистий куб, всередині якого мадридці люблять ховатися від спеки. Напис на кубі говорить: “Народ Мадриду - Конституції у 1978 року”. Куб, як відомо, служить одним із символів досконалості. Втілені в роботах фрранцузьких просвітителів ідеї свободи перекочували за океан разом з пам'ятником Свободи, який став символом Америки, американської демократії. Сучасне розуміння теорії поділу влади було в повному розумінні "матеріалізоване" при будівництві нової столиці Бразилії - міста Бразиліа, архітектурний вигляд якого був покликаний відобразити перетворення країни в індустріально-аграрну державу [1, 34]. Американська дослідниця Н. Евенсон відзначала, що “будівництво Бразилії - це перш за все спроба відтворити нові ідеали, відносини й образи" [2, 25].

Таким чином, як бачимо, культура являє собою досить складне у визначенні та розумінні явище, яке, тим не менш, має величезне значення для суспільства в цілому і для правової системи зокрема. Багатогранність і значимість даного явища потребують особливої уваги з боку сучасної науки.

Аналіз останніх досліджень. Порушена авторами проблема практично ще не була предметом окремого дослідження як у вітчизняній так і зарубіжній історіографії. Аналізуючи наукові праці з цієї тематики, відзначимо, що лише невелика кількість вчених досліджувала ії окремі аспекти в контексті вивчення більш ширших тематичних блоків. Тому теоретичну основу дослідження становлять праці класиків світової фрілософоської та правової думки, серед яких: Арістотель, М. Вебер, Г. Гегель, Г. Еллінек, Р. Ієрінг, Г. Кельзен, Ш-Л. Монтеск'є, А. Токвіль, Г. Шершеневич та ін. Спеціально теорія та історія конституціоналізму та культури в Україні досліджувалася такими вітчизняними ученими, як: А. Георгіца, В. Кампо, А. Крусян, О. Мироненко, М. Орзіх, М. Савчин, І. Словська, Н. Стецюк, П. Стецюк, В. Шаповал, С. Шевчук, Ю. Шемшученко та ін.

Мета статті. Метою статті є з'ясування місця та ролі культури у процесі формування основ конституціоналізму в державі та зокрема Конституції як Основного Закону держави.

Виклад основного матеріалу. Не менш важливими і, разом з тим, складними є питання формування і розвитку культури в правової державі. Вона нерозривно пов'язана з суспільством й індивідами, його складовими. Визначальне значення в сучасному суспільстві відіграє конституціоналізм, який являє собою сукупність конституційних ідей, а також наявність відповідного нормативноправового фрундаменту, досягнення певного фрактичного політичного режиму і систему захисту конституційного ладу і конституції $[3,45]$. Конституціоналізм передбачає наявність в суспільстві його основоположного акту - Конституції. Саме в Конституції визначені культурологічні засади сучасного суспільства та держави, а також права і свободи людини і громадянина. У зв'язку з цим нам видається важливим підкреслити, що саме Конституція є основою формування і розвитку правової культури [4, 523]. Невід'ємним фрактором впливу на культурологічний прояв змісту конституції, на наш погляд, $\epsilon$ політика держави. При цьому, у політичній сфері функції конституції нерозривно пов'язані з ії природою. Багато в чому від того, якої природи набуває конституція, залежить ефрективність ії дії у сфері політики. Адже природа конституції - це ії соціально-політичний зміст. У вітчизняному державознавстві ще в радянський час розмежовували класову природу конституції та її зміст. Під класовою природою розуміли основну соціально-політичну характеристику конституції. Вона знаходить свій прояв у її змісті, принципах, властивостях і функціях, здійснює вирішальний вплив на ії форму, визначаючи ії принципові риси. Зміст конституції - це конкретизація її класової природи. Причому зміст може змінюватися в рамках конкретної природи під впливом ряду об'єктивних і суб'єктивних чинників. Конституція мала подвійний зміст - соціальний та правовий [5, 39]. Річ у тому, що такий підхід ґрунтувався на фрормаційній теорії, відповідно до якої специфіка природи конституції в різних країнах прив'язувалася до певної суспільно-економічної формації. Протягом всього періоду розвитку радянських конституцій, навіть в пізній період, що отримав назву «розвиненого соціалізму», домінувало класове уявлення про природу конституції, яка визначалася тим, якому класу (класам) вона служить і який тип власності закріплює $[6,68]$.

На наш погляд, природа культурної функції конституції випливає з її соціально-політичного змісту, так би мовити, в концентрованому вигляді. Правовий зміст конституції визначається об'єктами конституційного регулювання, інакше кажучи, тим, які правові інститути, принципи та норми знаходять 
віддзеркалення в тексті конституції і у зв'язку з цим набувають статус конституційних. 3 урахуванням відмінностей правового та соціально-політичного змісту конституції, необхідно виділити ключові елементи її природи, які здійснюють політичний вплив на функціонування конституційних норм.

Ці елементи можна сфрормлювати у вигляді теоретичних постулатів, відповіді на які і дають загальне уявлення про природу конкретної конституції. До них відносимо: 1) воля яких політичних сил знайшла закріплення в конституційних нормах (чия політична воля була закріплена в конституції?); 2) інтереси яких соціальних прошарків відображаються в конституційних положеннях і підтримуються ними (чиї інтереси відображає і підтримує конституція?); 3) який ступінь легітимності конституції, яка багато в чому визначається умовами розробки її проекту і порядком її ухвалення (як вибраний порядок розробки та ухвалення конституції вплинув на ступінь її легітимності?).

У конкретно-історичних умовах і правовій культурі окремої країни відповіді на ці питання можуть розрізнятися. В конституційній історії однієї і тієї ж країни різні конституції можуть мати неоднакову сутність. Більше того, сутність однієї і тієї ж конституції з часом також може піддаватися перетворенню та віддалятися від первинного задуму її творців. Це пов'язано в першу чергу з тим, що можуть змінюватися соціально-політичні умови дії конституції, реалізації ії норм [7, 45].

У сучасному конституціоналізмі виділяють три основні підходи до розуміння природи конституції: ліберально-демократичний, марксистсько-ленінський, теологічний. Ці три напрями в конституційному праві по-різному вказують на основне призначення конституції в політичній сфері.

Ліберально-демократичний підхід сорормувався в кінці XVIII в., хоча він спирався на ідеї і цінності англійських і французьких просвітителів, які розроблялися в працях Дж. Локка, Ш. Монтеск'є, Ж. Руссо й інших в рамках школи природного права.

В основі ліберально-демократичного підходу лежить доктрина суспільного договору. Відповідно до неї конституція розглядається як результат суспільної згоди, компромісу між різними соціальними прошарками та політичними силами з приводу фундаментальних принципів організації суспільства та держави, взаємовідносин особи та держави. Конституція як суспільний договір - важливий показник політичного консенсусу, існуючого в суспільстві.

У країнах, де конституція давно діє в умовах високого політичного консенсусу, вона набуває характеру угоди, до якої кожне подальше покоління може додавати нові положення або змінювати існуючі. За визнанням американських конституціоналістів Н. Редліха, Б. Шварца і Дж. Аттаназіо, в «американському праві слово конституція має більш обмежене значення; вона $є$ писаною угодою, що передається від першого покоління американців до майбутніх поколінь» [8, 21]. Інший американський дослідник Д. Рейман стверджує, що основами американської конституційної демократії є права людини та суспільний договір, і розглядає конституцію з трьох боків: як писаний текст, як соціальну практику й як моральну обіцянку [9, 133].

Марксистсько-ленінський підхід отримав розвиток у другій половині XIX - початку XX в. Як теоретична концепція він фрормувався 3 ідей та поглядів, висловлених класиками марксизму (К. Марксом і Ф. Енгельсом) й істотно доповнених лідером більшовиків В. Леніним. Він прагнув пристосувати постулати класичного марксизму до соціально-політичних реалій Росії початку XX в. К. Маркс і Ф. Енгельс відзначали, що конституція, будучи результатом класової боротьби, встановлюється пануючим класом, класом який переміг. На їх думку, після захоплення влади пануючі класи повинні конституювати свою силу не тільки у вигляді держави, але і «надати своїй волі... загальний вираз у вигляді державної волі, у вигляді закону» [10, 122]. I таким законом, перш за все, є конституція. Підкреслюючи класовий характер конституції, В. Ленін писав: «природа конституції в тому, що основні закони держави взагалі та закони, що стосуються виборчого права до представницьких установ, їх компетенція та ін., виражають дійсне співвідношення сил в класовій боротьбі» [11, 535].

Теологічний підхід є певним поєднанням ідей світського та божественного права. Він з'явився значно пізніше за інші підходи як результат розповсюдження в XX ст. (переважно в другій його половині) конституційних ідей і принципів у країнах арабського Сходу, де домінуюче становище займають джерела мусульманського права. Уявлення про конституцію в цих країнах асоціюється із наданням божественних правил поведінки для «релігійної общини». Якщо конституція існує як писаний акт, вона не повинна суперечити найважливішому джерелу мусульманського права - Корану.

Конституція в цих країнах легітимує «ісламське правління» як особливу форму теократичної держави [13, с. 45]. Розкриваючи зміст ісламської республіки, у Конституції Ірану говориться, що вона заснована на вірі в Аллаха і його всеосяжну владу, в «божественне одкровення», що зумовлює будьякі закони, а також на вірі у відповідальність людини перед Аллахом (ст. 2). 3 роллю ісламу, як найважливішою політико-ідеологічною основою держави, пов'язано і ставлення до нього як до одного 3 легітимуючих чинників, що забезпечують стабільність правлячого режиму.

В українському суспільстві, що знаходиться на стадії модернізації своєї політичної, правової й економічної систем, ставлення до Конституції є приватним аспектом суспільного світогляду, розколеного диференціацією соціальних прошарків. У такому ставленні відображається процес нової стратифікації суспільства, що змінюється. Конституційний розвиток України в XX в. супроводжувавався декількома кардинальними змінами цивілізаційних основ існування суспільства та держави. Діючі конституції по-різному відображали баланс політичних сил і мали неоднаковий соціально-політичний 
зміст $[12,86]$. Конституція 1919 року відобразила й утілила політичний розвиток революційного авторитаризму. Суть його полягає в тому, що в цілому він спирається на широку демократичну основу, на відміну від цензових монархічних конституцій XIX - начало XX в. Логіка революційного авторитаризму виходила з принципу «Salus populi suprema lex est» (від лат. «благо народу - вищий закон»).

Конституція закріплювала нову політичну реальність союзу робітників і селян у цілях зростання народного блага. В. Ленін підкреслював, що радянська конституція не вигадується якою-небудь комісією та не списується з інших конституцій, не складається в кабінетах, а розробляється на основі досвіду боротьби трудящих і організації пролетарських мас [11, 45]. Проте турбота про народне благо вручалася революційному авангарду - комуністичній партії, представники якої, суміщаючи партійні та державні пости, застосовували авторитарні методи панування. Класовий підхід до конституції служив обґрунтовуванням вживання насильства до соціальних прошарків, що не розділяли мети революційного переходу до соціалістичного суспільства. Отже, Конституція 1919 р. виконувала не функцію обмеження державної влади, на відміну від ліберальних конституцій кінця XVIII в., а функцію обґрунтовування політичної влади, не обмеженої законом і правом, такої, що спирається на революційну законність і доцільність [12, 87].

Політичне значення диктатури пролетаріату збереглося і в наступних конституціях, прийнятих після утворення СРСР. Положення про диктатуру пролетаріату існували в Конституціях СРСР 1929 і 1937 рр. У процесі політичної еволюції соціальна основа диктатури пролетаріату поступово розширялася. По-перше, були ліквідовані соціальні прошарки, що виникають унаслідок свободи економічної діяльності, яка була заборонена в Радянській державі. По-друге, через систему місцевих рад прості верстви населення були залучені до участі в управлінні державою під політичним контролем правлячої партії більшовиків. По-третє, соціальна політика Радянської держави сприяла зростанню добробуту радянських громадян, хоча компартія залишалася головним інтерпретатором того, що вважалося «загальним благом». Можна погодитися з тим, що диктатура пролетаріату була «покликана просвітити маси, втягуючи їх в практичну роботу будівництва нового суспільства, а потім поступитися місцем народовладдю» $[14,22]$.

Після смерті Й. Сталіна та засудження культу особи в період правління М. Хрущова стала фрормуватися доктрина загальнонародної держави, яка знайшла втілення в нормах Конституції 1978 р. Ця доктрина включала декілька елементів, що відображали як спадкоємність з колишньою доктриною диктатури пролетаріату, так і новизну розуміння соціальної діяльності держави та завдань політичного розвитку. Розширення політичної участі радянських громадян через систему рад супроводжувалося збереженням політичного монізму партії - держави. Деяке послаблення принципу політичного монізму полягало в тому, що на державні посади почали допускатися безпартійні громадяни, а на виборах при збереженні безальтернативного голосування став висуватися єдиний блок «комуністів і безпартійних».

Конституція загальнонародної держави зберегла традиційно радянський підхід до співвідношення колективного й індивідуального. Вона носила переважно колективістський характер і ставила інтереси держави та суспільства вище за інтереси особистості $[15,108]$. Конституційні громадянські та політичні права і свободи, широко закріплені в конституційному тексті, не мали розгорненого механізму гарантій як на законодавчому рівні, так і на рівні судового захисту.

Після серпня 1991 р. розпад СРСР виявився неминучим, що привело до припинення дії Конституції СРСР 1977 р. із змінами та доповненнями. Надання Україні статусу суверенної держави перетворило Конституцію УРСР 1978 р. зі змінами та доповненнями з конституції однієї з союзних республік в Основний Закон самостійної держави. Ця Конституція продовжувала діяти в перехідний період 3 1990 по 1996 р. зі змінами в умовах політичної боротьби реформаторських сил і сил, що прагнули реанімувати радянську політичну систему.

Конституція України 1996 р. має принципово іншу природу, пов'язану з новими соціальнополітичними реаліями. Природа Конституції 1996 р. спочатку багато в чому визначалася політичними подіями, що відбулися в ході її розробки і напередодні її ухвалення. Проте перетворення, які відбулися після 1996 р. в різних галузях суспільного та державного життя, певний термін дії конституційних норм свідчать про поступову зміну та соціально-політичного змісту Конституції України [15, 109].

Саме тому сьогодні конституційний процес в Україні набирає обертів і з такою самою швидкістю ростуть занепокоєння в колах правознавців щодо наслідків прийняття Основного Закону. 3 одного боку, всі розуміють, що Конституція 1996 року спочатку містила у своєму тексті досить багато неточностей, протиріч, недомовленостей і посилань на закони, що досі не прийняті, а доля їхня покрита темрявою невідомості. 3 іншого боку, спостерігається надто небезпечна тенденція політизації процесу розробки та прийняття Конституції. Цією справою намагаються займатися політики й політтехнологи, замість юристів і правознавців. Як наслідок - виникла дещо тупикова ситуація. Нинішня Конституція не цілком задовольняє суспільство, й це погано, але інший варіант може бути ще гірший. Фактично, ледь прикрита юридичним одягом політична боротьба, що триває, відбувається на фоні надто низького інформування суспільства про її суть і проблеми конституційного процесу.

Отже, головною та до сьогодні невирішеною проблемою є неясність того, що пропонується приймати: нову Конституцію, нову редакцію нинішньої Конституції, зміни й доповнення до чинної Конституції. Хоч як це не парадоксально, але у виступах лідерів держави, ці терміни використовуються 
неодноразово як синоніми. Хоч з юридичного погляду за ними стоять абсолютно різні поняття. Ця термінологічна плутанина несе в собі велику небезпеку втрати орієнтирів і заважає чіткій постановці проблеми в суто правовій сфрері.

Висновки. Таким чином, саме Конституція є тим фундаментом, який визначає фрормування і розвиток правової культури в державі. Тому ми повинні керуватися правилом: яка Конституція країни, така і її правова культура.

Крім того, вважаємо, що, на жаль, конституційний процес сьогодні надто політизований. На нашу думку, триває найгостріша політична боротьба за прийняття зручної для однієї з сторін фрорми конституції. А фрактично - за владу - всі хочуть максимум влади. У тому числі й через проведену якимсь чином свою Конституцію. Однак Основний Закон повинен прийматися не з кон'юнктурних міркувань політичної доцільності, а бути повноцінним юридично вивіреним документом з урахуванням досягнень світового правознавства, з найсуворішим дотриманням усіх передбачених юридичних процедур. Адже конституція повинна бути головним документом держави, принаймні, на десятиріччя.

\section{תimepamypa}

1. Страшун Б.А. Конституционное (государственное) право зарубежных стран. Часть общая. Тома 1-2. Москва. 2000. $611 \mathrm{c}$

2. Ewenson N. Two Brasilian Capitals: Architecture und Urbanism in Rio de Janeiro and Brasilia. New Haven: 1975. 212 p.

3. Авакьян С. А. Конституция России: природа, эволюция, современность: 2-е изд. Москва: РЮИД, “Сашко”, 2000.

$510 \mathrm{c}$.

4. Шадрин В. В. Конституция как основа формирования и развития правовой культуры в России. Молодой ученый. 2015. №6. C. 523-526. URL https://moluch.ru/archive/86/16214/ (дата звернення: 11.07.2019).

5. Юдин Ю. Л. Конституции. Конституционное право развивающихся стран : предмет, наука, источники / отв. ред. В. Е. Чиркин. Москва: Юридическая литература, 1987. С. 38 - 42.

6. Фарберов Н. П. Новая Конституция СССР - манифест эпохи строительства коммунизма. Конституция развитого социализма. Москва: Восход-А, 1979. С. 67-81.

7. Бєлов Д.М. Парадигма українського конституціоналізму. Монографрія. В. Березний: РК «Євростандарт», 2011. 400 C.

8. Redlich N., Schwartz B., Attanasio J. Understanding Constitutional Law. Matthew Bender/Irwin, 1995. 211 p.

9. Reiman J. The Constitution, Rights, the Conditions of Legitimacy. Constitutionalism. The Philosophical Dimension / Ed. by Alan S. Rosenbaum. Westport (Conn.), 1988. P. 132-139.

10. Маркс К., Энгельс Ф. Соч. 2-е изд. Т. 1. Москва: Политиздат, 1991. 270 с.

11. Ленин В. И. Полн. собр. соч. Т. 36. Москва: Политиздат, 1980. 512 с.

12. Бєлов Д.М. Структура та зміст конституції: окремі аспекти. Науковий вісник Ужгородського національного університету. Серія «Право». Випуск 14. Частина 1. Ужгород: «Ліра». 2010. с. 80-87.

13. Салыгин Е. Н. Теократическое государство. Москва: Юридическая литература, 1999. 90 с.

14. Лукьянова Е. А. Значение Конституции СССР 1977 г. в развитии источников российского государственного права. Государство и право. 2001. № 4. с. $22-27$.

15. Селіванов В. Право і влада суверенної України : методологічні аспекти. Київ: Юридична думка, 2002. 211 с.

\section{References}

1. Strashun, B.A. (2000). Constitutional (state) law of foreign countries. Part of the total. Tom 1-2. Moscow [in Russian].

2. Ewenson, N. (1975). Two Brasilian Capitals: Architecture und Urbanism in Rio de Janeiro and Brasilia. New Haven [in English].

3. Avakyan, S.A. (2000). Constitution of Russia: nature, evolution, modernity: 2nd ed. Moscow: Ryuid, Sashko [in Russian].

4. Shadrin, V.V. (2015). Constitution as the basis for the formation and development of legal culture in Russia. Young scientist, 6. URL https://moluch.ru/archive/86/16214/ [in Russian].

5. Yudin, Yu.L. (1987). Constitution. Constitutional law of developing countries: subject, science, sources. V.E. Chirkin (Ed.). Moscow: Legal literature [in Russian].

6. Farberov, N.P. (1979). New Constitution of the USSR - a manifesto of the era of communist construction. Constitution of developed socialism. Moscow: Voskhod-A, [in Russian].

ian].

7. Byelov, D.M. (2011). The paradigm of Ukrainian constitutionalism. Monograph V. Berezniy: RK “Evrostandart” [in Ukrain-

8. Redlich, N., Schwartz, V., \& Attanasio, J. (1995). Understanding Constitutional Law. Matthew Bender / Irwin [in English].

9. Reiman, J. (1988). The Constitution, Rights, The Conditions of Legitimacy. Constitutionalism. The Philosophical Dimension. Ed. by Alan S. Rosenbaum. Westport (Conn.) [in English].

10. Marx, K., \& Engels, F. (1991). Soch. 2nd ed. Vol. 1. Moscow: Politizdat, 1991 [in Russian].

11. Lenin, V.I. (1980). Complete collection of works. Vol. 36. Moscow: Politizdat [in Russian].

12. Byelov, D.M. (2010). The structure and structure of the Constitution: environmental aspects. Science Bulletin of Uzhgorod National University. Seriya "Law". Issue 14. Part 1. Uzhgorod: "Lira" [in Ukrainian].

13. Salygin, E.N. (1999). The Theocratic State. Moscow: Legal literature [in Russian].

14. Lukyanova, Ye. A. (2001). The Value of the 1977 USSR Constitution in the Development of Sources of Russian State Law State and law, 4. [in Russian].

an].

15. Selivanov, V. (2002). Law and the sovereign sovereign Ukraine: methodological aspects. Kyiv: Legal thought [in Ukraini- 